\title{
Mucosal Melanoma of the Head and Neck cM1 TNM Finding v7
}

National Cancer Institute

\section{Source}

National Cancer Institute. Mucosal Melanoma of the Head and Neck cM1 TNM Finding v7. NCI Thesaurus. Code C89144.

Mucosal melanoma of the head and neck with distant metastasis. (from AJCC 7th Ed.) 